Игорь Иванович КАЛИГАНОВ 


\section{СВЯТОЙ БЛАГОВЕРНЫЙ КНЯЗЬ ЛАЗАРЬ СЕРБСКИЙ, ПОГИБШИЙ В БИТВЕ С ТУРКАМИ НА КОСОВОМ ПОЛЕ ${ }^{1}$}

\section{Аннотация:}

Статья посвящена князю Лазарю, правившему Сербией в XIV в. около двух десятков лет и погибшему затем в битве с турками на Косовом поле в 1389 г. Он проявил себя успешным правителем и дипломатом, сумел объединить значительную часть разрозненных сербских земель, укрепить династические связи со своими балканскими соседями, урегулировать конфликт Сербской церкви с Константинопольской патриархией. Почти сразу же после гибели князь Лазарь был провозглашен святым мучеником. Его фигура заняла видное место в сербской литературе и фольклоре. Культ князя Лазаря в XVI в. проник в Московское государство, но был менышим по сравнению с почитанием в русских землях св. архиепископа Саввы Сербского и св. Симеона Сербского.

\section{Ключевые слова:}

Сербия, князь Лазарь, гибель в битве с турками, канонизация, отражение его фигуры в литературе и фольклоре, культ в русских землях.

Abstract: I.I. Kaliganov "The Holy Blessed Prince Lazarus of Serbia who died in the BATTLE WITH THE TuRKS ON KOSOVO FIELD".

The article is dedicated to Prince Lazarus, who ruled Serbia in the14th century for about two decades and died in the battle with the Turks on Kosovo field in 1389. He proved to be a successful ruler and diplomat, managed to unite a large part of the scattered Serbian lands, strengthen dynastic ties with his Balkan neighbors and resolve the conflict of the Serbian Church with the Constantinople Patriarchate. Almost immediately after his death, Prince Lazarus was proclaimed a holy martyr. His figure took a prominent place in Serbian literature and folklore. The cult of Prince Lazarus in the 16th century entered the Moscow state, but was less important than the veneration in Russian lands of St. Sava of Serbia and St. Simeon of Serbia.

\section{Keywords:}

Serbia, Prince Lazarus, death in battle with the Turks, canonization, reflection of his figure in the Serbian literature and folklore, his cult in the Russian lands.

К нязь Лазарь Хребелянович (ок. 1320-1389) - правитель Сербии, один из главных героев битвы против турок на Косовом поле в 1389 г., отразившейся в сербской литературе и фольклоре, после гибели почти сразу же был причислен Сербской Православной Церковью к лику св. великомучеников.

\footnotetext{
1 Работа выполнена при финансовой поддержке РФФИ (грант № 18-512-76004).
} 
Он начал править Сербией не в самое лучшее для нее время. Страну раздирали усобицы крупных феодалов, часть территории бывшего сербского государства заняли воинственные соседи. С юга на северные Балканы напирали турки, в 1371 г. одержавшие над сербами победу на реке Марице. Почти одновременно прервалась и линия династии Неманичей, которые правили Сербией более двухсот лет. Последний ее представитель, царь Стефан Урош V умер тогда же, не оставив после себя наследников. Среди претендентов на управление страной верховенства добился придворный аристократ Лазарь, сын царского логофета (начальника канцелярии) по имени Прибац, владевшего городком Прилепец на р. Южная Морава. Укреплению Лазаря во власти во многом способствовал его брак с аристократкой Милицей, которая находилась в дальнем родстве с царствовавшей прежде динас-

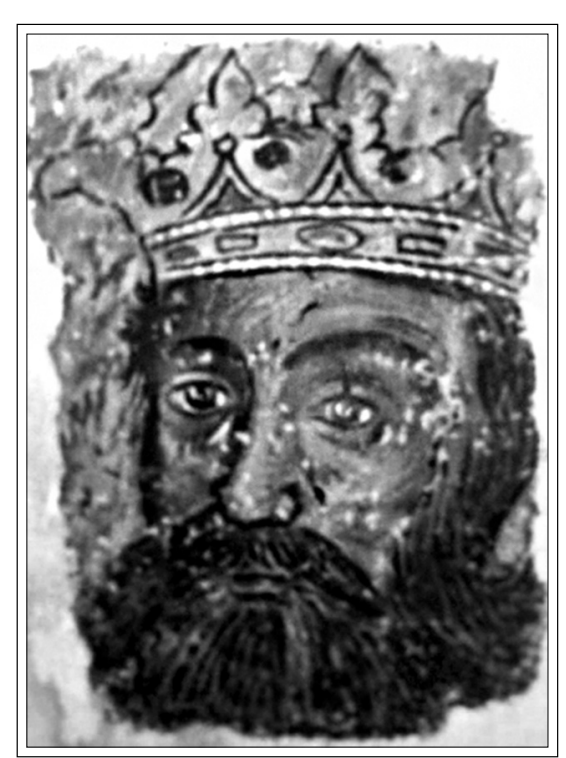

Св. Лазаръ, князъ Сербский. Прорись прижизненного портрета в монастыре Раваница. $1385-1387$ тией Неманичей. Лазарь оказался успешным правителем и дипломатом. Он расширил военные и политические связи с соседями, выдав своих дочерей в жены владевшему областью Косова и Северной Македонией Вуку Бранковичу, Александру - сыну болгарского царя Ивана Шишмана из Тырново, и сербскому правителю северной Албании Георгию Балшичу. Кроме того, ему удалось урегулировать длительный конфликт между Сербской Православной Церковью и Константинопольской патриархией из-за самовольного поставления сербами своего патриарха в 1345 г. без согласования с ней вопроса о легитимности столь важного церковно-юридического акта.

Увеличив свои земельные владения, Лазарь не стал претендовать на царский или королевский статус, а довольствовался титулом князя. Поэтому ученые позднее стали называть период его правления «княжевиной». Помимо политического укрепления страны, князь Лазарь существенно улучшил ее экономическое состояние и приступил к созидательной деятельности. В столице княжества г. Крушевац по его распоряжению была воздвигнута великолепная церковь первомученика Стефана («Лазарица»), он основал свою будущую усыпальницу - «задужбину» Раваница (монастырь Вознесения Христова - крепость с мощными стенами и башнями) и построил обитель Пресвятой Богородицы в Велудже. Возводившиеся храмы имели специфические черты, ставшие затем приметами Моравской школы в сербской архитектуре. Их стены представляли собой чередующиеся слои из тесаного известняка с тремя рядами кирпичей и имели декоративные глу- 
хие арки, крестообразные кровли покрывались свинцом или черепицей, барабаны куполов были высокими и узкими, а основное помещение располагало боковыми конхами-капеллами. Выступил князь Лазарь и щедрым ктитором ряда афонских монастырей, в том числе сербского Хиландарского, русского св. Пантелеймона и греческой Лавры св. Афанасия. При дворе князя Лазаря в Крушеваце обрели приют многие писатели и ученые, покинувшие свои родные места из-за военной экспансии турок на Балканах.

Турецкое завоевание балканских земель осуществлялось последовательно и методично. Победы и поражения в нем турок чередовались неоднократно. Самым знаменитым из сражений сербов с турками стала битва на Косовом поле, произошедшая 15 июня 1389 г. в день св. Вита (по-сербски - «Видовдан»). Именно она наиболее глубоко отразилась в сербской народной памяти и воплотилась в памятниках сербской литературы и фольклора. В этой битве во главе с князем Лазарем приняли участие объединенные силы балканских народов (сербы, боснийцы, хорваты, венгры, валахи и албанцы) общим числом приблизительно 12-20 тыс. человек. Им противостояло турецкое войско под началом султана Мурада, превосходившее их по численности в полтора раза. Кровопролитное сражение продолжалось целый день с переменным успехом для обеих сторон. Известное замешательство в турецком стане наступило после неожиданной гибели султана Мурада. В ставку к нему под предлогом важного сообщения явился сербский витязь Милош Обилич и, когда его подвели к Мураду, молниеносно извлек кинжал из складок одежды и заколол его на глазах телохранителей и придворных. Турки растерзали обидчика, но были ошеломлены случившимся. Этой критической ситуацией воспользовался сын султана Баязид: он приказал удавить своего соперника брата Якуба и повел турок на сербов в яростную атаку. Раненный князь Лазарь попал в плен, доставлен в шатер Мурада и обезглавлен над его телом. Турки одержали по-

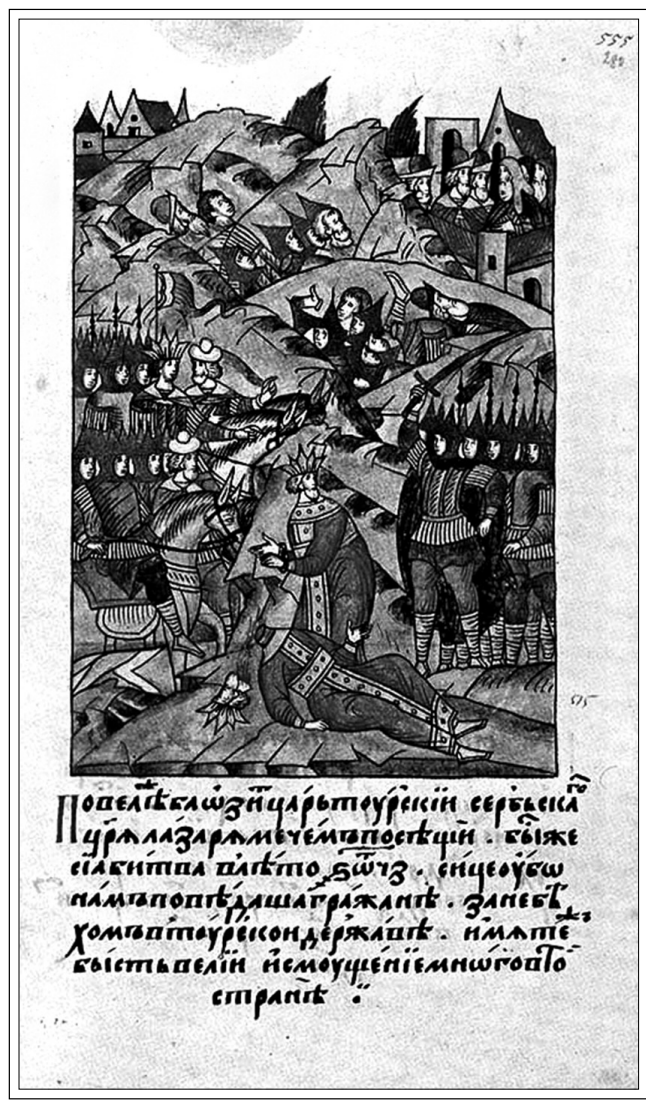

Гибель князя Лазаря на Косовом поле. Миниатюра

Лицевого Летописного свода. Середина XVI в. 
беду, но и сами понесли тяжелые потери, и их напор на север Балкан сравнительно уменьшился. Сербия попала от турок в вассальную зависимость, но смогла отстаивать свою неполную свободу еще целых 70 лет.

Родственники выкупили тело князя Лазаря, и спустя несколько лет оно было погребено в княжеской усыпальнице в Раванице. Церковь провозгласила казненного турками Лазаря святым великомучеником - православным, принявшим смерть за Христа от иноверных. В честь ставшего страдальцем Христовым верховного правителя в сербской литературе на протяжении полувека было создано около двух десятков произведений: пространных и кратких житий, похвальных слов, служб, канонов, тропарей и стихир. Некоторые из них были очень необычны по характеру материала, на котором они были запечатлены. Так, например, Елена, вдова погибшего в 1371 г. на реке Марице деспота Иоанна Углеши (в монашестве Евфимия) вышила золотыми и серебряными нитками текст похвалы князю Лазарю на покрове для раки святого. А сын князя, деспот Стефан Лазаревич, предположительно, выступил автором поэтической эпитафии отцу на мраморном столпе, который был установлен на Косовом поле. Остальные произведения были вполне традиционными (письменные тексты на пергамене и бумаге) и принадлежали известным или анонимным средневековым авторам. Среди первых находились сербский патриарх Даниил III, составивший похвальное слово князю Лазарю в 90-х годах XIV в., и грек Антоний Рафаил Эпактит, написавший произведение о страдальце аналогичного жанра.

Другие посвященные князю Лазарю агиографические и гимнографические произведения того периода являются анонимными. К таковым относятся проложное житие со стихом, сопровождающее текст службы; житие князя Лазаря, «Слово и отчасти от жития воспоминание», «Житие и начальство», вошедшее в так называемую Печскую летопись. Весьма многочисленными были и посвященные св. князю Лазарю анонимные церковные песнопения. Здесь прежде всего следует назвать стихиры и тропарь Лазарю, составленные для прославления святого по случаю принесения его мощей в Раваницу. Видимо, в том же монастыре в начале XV в. была написана и служба великомученику с двумя канонами, причем первый из них содержит в себе акростих «Лазаря похвалити, Боже мой, разум даруй ми». Со второй половины XV в развитии культа св. Лазаря произошла приостановка на полтора века - лишь в 90-х годах XVII столетия известный переписчик рукописей, иеромонах Киприан из монастыря Рача создал новую посвященную князю Лазарю стихиру. Ослабление традиции церковного почитания данного святого отчасти компенсировала сербская устная народная традиция. Особенно широкое распространение она получила после «Великого переселения» части сербов в австрийские владения в 1690 г. Князь Лазарь становится одним из главных героев фольклорного Косовского цикла, в котором часто обыгрывается сюжет с усеченной головой мученика. C XVIII в. фольклорные веяния стали заметны в сербской лите- 
ратуре, о чем свидетельствуют «Притча о косовском бое», Троношский родослов и, отчасти, «Сербская хроника» Георгия Бранковича.

Сведения о Косовской битве и гибели князя Лазаря к концу XIV столетия достигли Московской Руси, но какие-либо сербские письменные памятники о святом долго были русским людям неизвестны. Косвенные сведения о случившемся проникали на Русь главным образом посредством рассказа о Косовской битве и гибели князя Лазаря, который читался в житии его сына Стефана Лазаревича, составленном болгарским писателем Константином Костенецким. Оно начало распространяться в северо-восточных русских землях с первого десятилетия XVI в., и косовский сюжет из него попал во все редакции Русского Xронографа XVI - XVII вв., начиная с первой из них, составленной иеромонахом Досифеем (Топорковым) между 1516 и 1522 гг. Позднее данный сюжет был включен и в Никоновскую летопись. В середине XVI в. хиландарский игумен Паисий, наряду с другими дарами Ивану Грозному, привёз в Москву икону и службу князю Лазарю Сербскому. Видимо, с этого времени служба этому сербскому мученику и начала распространяться в русской рукописной традиции, но она пока еще слабо изучена. Известны, по крайней мере, два русских списка службы Лазарю Сербскому конца XVI столетия в служебных минеях, находившихся в Усть-Орле и Сольвычегодске - вотчинах богатейшего русского промышленника Никиты Строганова. В 80-х годах этого же столетия русские певчие распели и снабдили музыкальной знаменной нотацией отдельные стихиры князю Лазарю. Примером этому могут служить материалы из датируемого «не позднее 1586 г. певческого сборника Кирилло-Белозерского монастыря.

Древнейшим русским изображением князя Лазаря в Московской Руси считается одна из стенописей 1564 г. Архангельского собора в Московском Кремле - усыпальницы великих русских князей и царей вплоть до Петра I. Сюда князь Лазарь попал заодно с другими сербскими подвижниками святыми Симеоном и Саввой, культ которых в русскую землю проник значительно ранее. В целом можно отметить более слабое распространение почитания князя Лазаря в Московской Руси по сравнению с другими известными южнославянскими подвижниками - Иваном Рильским, Саввой и Симеоном Сербскими и Георгием Новым. Но объяснять это слабой связью с Москвой сербского монастыря Раваница, где хранились мощи подвижника (его иноки впервые приехали в русскую столицу лишь в 1693 г.) было бы ошибкой. Ведь культ данного сербского мученика проник в Москву через Афон еще за полтора века до этого. Скорее всего, причину следует искать в концептуально-политических соображениях Московского государства. Св. князь Лазарь стал среди сербов яркой культовой фигурой как первый верховный правитель православной страны, павший в битве против магометан. Но он не мог сделаться подобной значительной фигурой для почитания среди русских - жителей православного государства, чьи правители готовились к решительной борьбе с Казанью, Астраханью 
и Крымом и развивали идею Москвы - третьего Рима. Это стало бы напоминанием о возможном поражении в такой борьбе русского воинства и гибели только что венчавшегося на царство первого русского легитимного самодержца Ивана Грозного или тех, кто вставал во главе России вслед за ним. Кроме того, отсутствовали и основания для причисления князя Лазаря к лику великомучеников (наиболее близких к Богу святых), каковым он называется в одном из первых посвященных ему сербских житий. Князь не прошел через вереницу ужасных мучений во имя Христа, и перед ним не стояла альтернатива смены веры ради спасения собственной жизни казнь его была практически мгновенной и вызвалась чувством мести турок за гибель султана Мурада. Вероятно, именно поэтому в последующих сербских житиях и более поздних русских письменных источниках он стал фигурировать как св. «блаженный» или «благоверный» князь Лазарь Сербский.

\section{ЛИТЕРАТУРА}

Алексеев С.В. Памятники сербской средневековой агиографии XIV-XVII вв.

Переводы и исследования. Санкт-Петербург, 2017. Т. 2. Жития XIV-XVII вв. Родословы. Летописи. 462 с.

Трифуновић Ђ. Српски средњовековни списи о кнези Лазару и Косовском боју. Крушевац: Багдала, 1978.

\section{СПИСОК ИЛЛЮСТРАЦИЙ}

1. Монастырь Вознесения Христова в Раванице. 1375-1377 гг.

2. Крушевацкая крепость.

3. Собор св. первомученика Стефана (Лазарица) в Крушеваце. Ок. 1377-1380 гг.

4. Князь Лазарь. Прорись фрески (прижизненного портрета) в монастыре Вознесения Христова в Раванице. 1385-1387 гг.

5. Памятный монумент Газиместан на Косовом поле.

6. Похвала князю Лазарю на покрове. Монахиня Евфимия. 1402 г.

7. Свв. Князь Лазарь и княгиня Милица. Фреска монастыря Успения Богородицы в Любостини. Около 1403 г.

8. Миниатюра с изображением гибели князя Лазаря на Косовом поле. Лицевой Летописный свод. Второй Остермановский том. Середина XVI в.

9. Фреска с изображением князя Лазаря на столпе кремлевского Архангельского собора. 1564 г. под записью XVII в.

10. Свв. великомученики князь Лазарь и Георгий Новый. Икона Хиландарского монастыря. Середина XVI в. 